\title{
MULTIVARIABLE CONTROL OF SOLAR BATTERY POWER: ELECTROTECHNICAL COMPLEX AS OBJECT WITH HESSIAN-DRIVEN GRADIENT FLOWS
}

\author{
A.Yu. Sologubov, andrewsteelmaker@gmail.com, \\ I.M. Kirpichnikova, kirpichnikovaim@susu.ru \\ South Ural State University, Chelyabinsk, Russian Federation
}

\begin{abstract}
The paper presents certain development results for the novel extremum seeking controller based on Nesterov's gradient flows for solar tracking systems. It achieves convergence to an arbitrarily small neighborhood of the set of the cost function optimizers. Our results evident ate that for arbitrarily large compact sets of initial conditions, and arbitrarily small neighborhoods of the optimizer, the controller can be tuned to guarantee convergence taking into account the influence of the Hessian, as well as with tuning parameters that have a fairly clear physical meaning. The influence of the Hessian as a vector field, which is a reflection of the distortion of transient processes in the system, and taking it into account is an urgent task, since it allows for a more flexible impact on the speed of transient processes, and by endowing the system with some damping and smoothing, also for its improved quality.
\end{abstract}

Keywords: solar panel power, maximum power point tracking, nonlinear control system; extremum seeking, gradient flow, hessian.

\section{Introduction}

Solar tracking systems must operate in very specific modes, which impact the structure of the entire electrical complex [1]. The most important feature is the need to search for the point of maximum energy efficiency [2], fixation at this point and ensuring tracking when changing its position. This fact forces the developers to apply special control systems structures.

Much attention is devoted to the study of various aspects of MPPT-control, which was created based on the principles of extremum search [3]. According to the key bibliographic databases, over the past 17 years, more than 4000 articles on this topic have been published. They include brief reports, reviews, results of theoretical and experimental research. The subtleties and unresolved issues of these works are summarized in reviews, analytical and experimental studies [4-7].

Electric drive control systems for tracking the Sun are almost on par in the number of published articles on MPPT. The most useful of these are [5, 8-13]. As for poorly studied aspects of the issue, the research on MPPT controllers and electric drive control for tracking the sun does not come into contact with each other as much as expected. In our opinion, an important drawback of the MPPTs is that they look for power only by searching for the "optimal state" of the electrical circuit, to which the solar battery is connected [14]. In cases when the solar battery is oriented incorrectly, maximum generated power is lower.

A number of papers [15-17] consider the problem of the transient processes quality in systems for searching for an extremum with auxiliary modulation. The essence of these works lies in the fact that the Hessian and the gradient are in most cases in a nonlinear relationship. The elimination of this relationship is difficult, since in some cases, at the extremum point, it is impossible to obtain the inverse of the Hessian value (as is done in some continuous analogs of Newton's method), and establishing the exact relationship is a nontrivial problem. Thus, the set of second derivatives along the corresponding extremum search channels can be represented as a vector field distorting the transient process. We propose a solution that allows establishing the relationship between the Hessian and the gradients using the Nesterov accelerated flow and to increase the speed and quality of transients in the system.

This paper is organized as follows: Section II describes theory and problem statement, Section III presents computational results. Section IV briefly describes discussion questions. Finally, Section V presents some conclusions.

\section{Solar Battery and Extremum Seeking}

The starting point in our work is to reveal the dependence of the generated photocurrent on the intensity of radiation $\mathrm{G}_{\mathrm{exH}}$ incident on the surface of the solar battery and increasing with increasing temperature:

$$
\begin{aligned}
& \mathrm{I}_{\mathrm{ph}}=\frac{\mathrm{G}_{\mathrm{exH}}}{\mathrm{G}_{0}} \cdot\left(\mathrm{I}_{\mathrm{sc}}+\mathrm{k}_{\mathrm{I}_{\mathrm{sc}}} \cdot \Delta \mathrm{T}\right)= \\
& =\frac{\mathrm{G}_{\mathrm{exH}}}{\mathrm{G}_{0}} \cdot\left(\mathrm{I}_{\mathrm{sc}}+\mathrm{k}_{\mathrm{I}_{\mathrm{sc}}} \cdot\left(\mathrm{T}-\mathrm{T}_{0}\right)\right),
\end{aligned}
$$

where $\mathrm{G}_{0}$ - irradiance at the standard test conditions (STC) $\left(\mathrm{G}_{0}=1000 \mathrm{Wt} / \mathrm{m}^{2}\right) ; \mathrm{G}_{\mathrm{exH}}$ - extraterrestrial solar radiation, $\mathrm{Wt} / \mathrm{m}^{2} ; \mathrm{k}_{\mathrm{I}_{\mathrm{sc}}}-$ current/temperature coefficient [18]; $\Delta \mathrm{T}$ - difference between air temperature and temperature at STC.

Equation (1) shows that when $\mathrm{G}_{\mathrm{exH}}=0$, the solar battery is inactive. When the radiation is caught by the solar cell, it generates a photocurrent $\mathrm{I}_{\mathrm{ph}}$. Using 
the Kirchhoff I law [19], we can see, that at STC the current is determined by dependence $[19,20]$ :

$$
\begin{aligned}
& I=I_{p h}-I_{d}-I_{R_{s}}= \\
& =I_{p h}-I_{0} \cdot\left(e^{\frac{q \cdot\left(V+I \cdot R_{s}\right)}{n \cdot k \cdot T}}-1\right)-\frac{V+I \cdot R_{s}}{R_{s h}},
\end{aligned}
$$

where some physical constants and passport data: $\mathrm{I}_{\mathrm{ph}}$ - photocurrent at existing level of irradiance $\mathrm{G}_{\mathrm{exH}}, A$; $\mathrm{k}$ - Boltzmann constant, $1.3805 \cdot 10^{-23} \mathrm{~J} / \mathrm{K} ; \mathrm{q}-$ electron charge, $1.6021 \cdot 10^{-17} \mathrm{C} ; \mathrm{T}-$ cell temperature (at STC $=298 \mathrm{~K}$ ).

Parameters from analytical computations: $\mathrm{I}_{0}$ saturation current, $A ; R_{s}-$ series resistance, Ohm; $\mathrm{R}_{\mathrm{sh}}$ - parallel resistance, Ohm; $\mathrm{n}$ - ideality coefficient, for different semiconductors it's values from $1.2 \ldots 5$ [18, p. 2].

The analytical assessment allows constructing the volt-watt and volt-ampere characteristics of solar batteries with the smallest deviations from the passport data [20-22]. In [23] and in [20, 24], these parameters are calculated in a certain way to reflect the modes of short circuit, maximum power and no-load.

To calculate $b$ between the short circuit and the no-load, equation (1) is transformed into a nonrecursive formula for $\mathrm{I}-\mathrm{V}$ characteristics $(\mathrm{P}-\mathrm{V}$ by multiplied on $\mathrm{V})$ :

$$
\left\{\begin{array}{c}
I=\frac{\left(-W\left(0,-\frac{I_{0} \cdot R_{s} \cdot R_{s h} \cdot e^{p_{2}}}{n \cdot k \cdot T \cdot\left(-R_{s}-R_{s h}\right)}\right)+p_{2}\right) \cdot n \cdot k \cdot T-q \cdot V}{q \cdot R_{S}} ; \\
p_{2}=\frac{R_{s h} \cdot q \cdot\left(I_{0} \cdot R_{S}+I_{p h} \cdot R_{S}+V\right)}{\left(n \cdot k \cdot T \cdot\left(R_{s}+R_{s h}\right)\right)},
\end{array}\right.
$$

where $\mathrm{W}(0, \sim)$ - general axis of Lambert function.

Extraterrestrial solar radiation on Earth $\mathrm{G}_{\mathrm{exH}}$ can be calculated as [24]:
$\mathrm{G}_{\mathrm{exH}}=\mathrm{G}_{\mathrm{ex}} \cdot \cos (\xi)$

where $\mathrm{G}_{\mathrm{ex}}$ - extraterrestrial radiation, $\mathrm{Wt} / \mathrm{m}^{2}$.

Incidence coefficient $\xi$ for the surface oriented in any direction we can calculate as follows [25]:

$$
\begin{aligned}
& \xi=\cos (\Theta) \cdot \cos (\theta)+ \\
& +\sin (\theta) \cdot \sin (\Theta) \cdot \cos (\Gamma-\gamma),
\end{aligned}
$$

where $\theta$ is the zenith angle measured from horizontal axis; $\gamma$ is the azimuth angle, measured from south to surface normal on the horizontal axis; $\Theta, \Gamma$ - topocentric elevation angle (TEA) and Azimuth angle (AA) of the Sun.

This function on the extremum on the standard intervals $0 \leq \theta \leq 90^{\circ}$ и $0 \leq \gamma \leq 360^{\circ}$ shows that at the specified interval $0 \leq \theta \leq 90^{\circ}$ and $0 \leq \gamma \leq 360^{\circ}$ $\left(\frac{\partial^{2} \xi}{\partial \theta^{2}}\right) \cdot\left(\frac{\partial}{\partial \gamma}\left(\frac{\partial \xi}{\partial \theta}\right)\right)-\left(\frac{\partial^{2} \xi}{\partial \gamma^{2}}\right)^{2} \geq 0$, and $\frac{\partial^{2} \xi}{\partial \theta^{2}}<0$, and when $\theta=\Theta$ и $\gamma=\Gamma$, that is global maximum point for $\xi$ on a typical interval. When this condition $\xi=1$.

The component of the photocurrent, depending on the level of the ratio of the current illumination and illumination in the STC, naturally enters the equation (1), therefore, we rewrite it as:

$$
\mathrm{I}=\frac{\mathrm{G}_{\mathrm{exH}} \cdot \xi}{\mathrm{G}_{0}} \cdot \mathrm{I}_{\mathrm{sc}}-\mathrm{I}_{0} \cdot\left(\mathrm{e}^{\frac{\mathrm{q} \cdot\left(\mathrm{V}+\mathrm{I} \cdot \mathrm{R}_{\mathrm{s}}\right)}{\mathrm{n} \cdot \mathrm{k} \cdot \mathrm{T}}}-1\right)-\frac{\mathrm{V}+\mathrm{I} \cdot \mathrm{R}_{\mathrm{s}}}{\mathrm{R}_{\mathrm{sh}}} .
$$

This formula describes photocurrent of the solar battery, dependent on $\mathrm{V}$, but also on $\xi$, i.e., from the angle of zenith and azimuth of the panel.

Hence, the solar battery extremum seeking will be multi-parameter (3, to be more precise), and $\mathrm{P}_{\max }=\mathrm{P}(\mathrm{V}, \theta, \gamma)$. Now let's look at the most essential aspects of the structure of a multiparameter system of extremum seeking. The block diagram built for our solution is shown in Fig. 1.

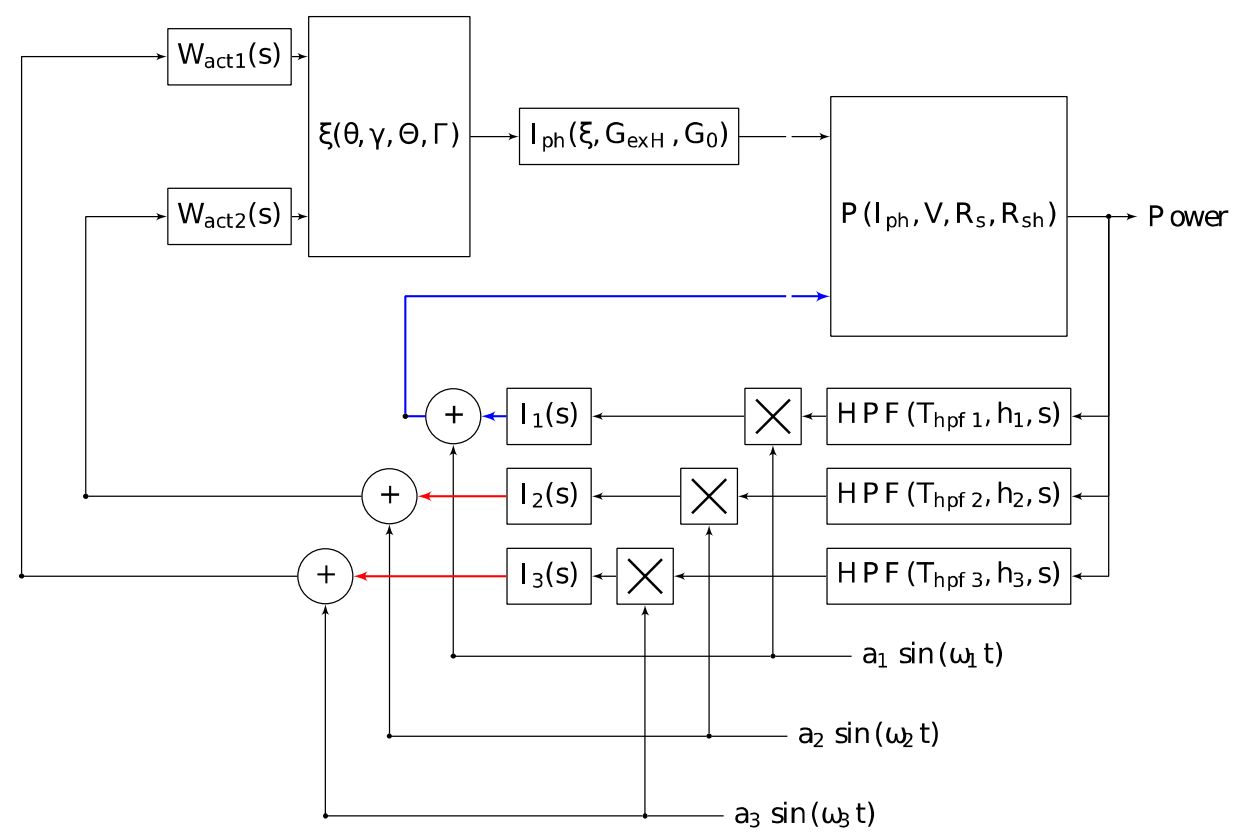

Fig. 1. Multivariable extremum seeking for solar battery.

Red line is the coordinate electric drives-contours. Blue line is the MPPT-contour 

lude:

This extremum seeking control system inc-

1. Solar battery. Some parameters obtained using impedance spectroscopy [26]. If the actual values of the $C_{T}, C_{D}$ and differential resistance $R_{d}$ have same numerical order, then solar battery have transfer function in following form $\mathrm{W}_{\mathrm{C}}=\frac{1}{\mathrm{~T}_{\mathrm{C}} \cdot \mathrm{s}+1}$ with very small time constant $\mathrm{T}_{\mathrm{C}} \approx 10^{-9} \ldots 10^{-8}$ in the $\mathrm{I}_{\mathrm{ph}} \rightarrow \mathrm{V}$ transmission channel.

2. High-pass filter $\left(\mathrm{HPF}_{\mathrm{i}}\right)$ with transfer function $\mathrm{W}_{\mathrm{HPF}_{\mathrm{i}}}=\frac{\mathrm{s}}{\mathrm{s}+1}$.

3. Demodulator.

4. Modulator.

5. Control integrator $I_{i}$ with high or small gain $\mathrm{k}_{\mathrm{i}}$.

6. Electric drives with transfer function $\mathrm{W}_{\mathrm{act}_{\mathrm{i}}}=\frac{1}{\mathrm{~T}_{\mathrm{act}_{\mathrm{i}}} \mathrm{s}+1}$.

Classical extremum search system with auxiliary modulation, taking into account the presented linear dynamic models, is described by the system of differential equations (in addition, we have included an additional filter and baseband signal in the control system for evaluating the Hessian. This block works according to the principles similar to the gradient estimation block):

$$
F=\left\{\begin{array}{c}
\dot{\mathrm{z}}=-\mathrm{z}+\dot{\mathrm{P}}\left(\mathrm{x}_{1} \ldots \mathrm{x}_{3}\right) \\
\vdots \\
\dot{\mathrm{x}_{1}}-\mathrm{k}_{1} \cdot \mathrm{g}_{1}=0 \\
\left(\mathrm{o}_{1}^{\mathrm{d}} \ldots \mathrm{o}_{1}\right)=\mathrm{x}_{1}+\mathrm{s}_{1} \\
\dot{\mathrm{g}_{1}}=-\mathrm{g}_{1}+\mathrm{z} \cdot \mathrm{s}_{1} \\
\dot{\mathrm{h}_{1}}=-\mathrm{h}_{1}+\mathrm{z} \cdot \mathrm{h}_{1} \\
\vdots \\
\dot{\mathrm{x}_{\mathrm{n}}}-\mathrm{k}_{\mathrm{n}} \cdot \mathrm{g}_{\mathrm{n}}=0 \\
\left(\mathrm{o}_{\mathrm{n}}^{\mathrm{d}} \ldots \mathrm{o}_{\mathrm{n}}\right)=\mathrm{x}_{\mathrm{n}}+\mathrm{s}_{\mathrm{n}} \\
\dot{g_{\mathrm{n}}}=-\mathrm{g}_{\mathrm{n}}+\mathrm{z} \cdot \mathrm{s}_{\mathrm{n}} \\
\dot{\mathrm{h}_{\mathrm{n}}}=-\mathrm{h}_{\mathrm{n}}+\mathrm{z} \cdot \mathrm{m}_{\mathrm{n}}
\end{array}\right.
$$

where $z, x_{1} \ldots x_{n}, o_{1} \ldots o_{n}, g_{1} \ldots g_{n}, h_{1} \ldots h_{n}-$ statevariables of an electrical complex as a dynamic system; $\mathrm{P}\left(\mathrm{x}_{1} \ldots \mathrm{x}_{3}\right)$ - generalized extreme characteristic of the solar battery power, taking into account all the channels on which the maximum power depends; $\mathrm{n}$ - the number of contours of the extremum seeking, that is equal to the number of variables on which solar battery power depends; $s_{i}=\alpha_{i} \cdot \sin \left(\omega_{i} \cdot t\right)$, $\mathrm{m}_{\mathrm{i}}=\frac{16}{\alpha_{\mathrm{i}}{ }^{2}}\left(\sin \left(\omega_{\mathrm{i}} \cdot \mathrm{t}\right)^{2}-\frac{1}{2}\right)-$ an auxiliary search signal corresponding to i-channel with an appropriate amplitude and frequency, or the condition must be met $\omega_{\mathrm{i}} \neq \omega_{\mathrm{j}} ; \dot{\mathrm{x}}_{\mathrm{i}}-\mathrm{k}_{\mathrm{i}} \cdot \mathrm{g}_{\mathrm{i}}=0$ - differential equation equivalent to the gradient descent, the simplest gradient flow along $\mathrm{i}$-channel; $\mathrm{k}_{1} \ldots \mathrm{k}_{\mathrm{i}}$ - positive constants representing the gains to increase the rate of convergence to the extremum.
Assumption: If we assume that, with a sufficient degree of quality, $\mathrm{z} \cdot \mathrm{s}_{\mathrm{i}}$ corresponds to the true gradient $\nabla_{\mathrm{x}_{\mathrm{i}}} \mathrm{P}\left(\mathrm{x}_{1} \ldots \mathrm{x}_{3}\right)$, i.e. $\mathrm{z} \cdot \mathrm{s}_{\mathrm{i}} \approx \nabla_{\mathrm{x}_{\mathrm{i}}} \mathrm{P}\left(\mathrm{x}_{1} \ldots \mathrm{x}_{3}\right)$ and $\mathrm{z} \cdot \mathrm{m}_{\mathrm{i}} \approx \nabla_{\mathrm{x}_{\mathrm{i}}}^{2} \mathrm{P}\left(\mathrm{x}_{1} \ldots \mathrm{x}_{3}\right)$, taking into account the elimination of additional corrections using the amplification factor $\mathrm{k}_{\mathrm{i}}$, we can represent the extremum seeking system as a reduced system characterizing the gradient descent along many coordinates:

$$
F \approx\left\{\begin{array}{c}
\dot{x_{1}}-k_{1} \cdot g_{1}=0 \\
\left(o_{1}^{d} \ldots o_{1}\right)=x_{1} \\
\dot{g_{1}}=-g_{1}+\nabla_{x_{1}} P\left(x_{1} \ldots x_{3}\right) \\
\dot{h_{1}}=-h_{1}+\nabla_{x_{1}}^{2} P\left(x_{1} \ldots x_{3}\right) \\
\vdots \\
\dot{x_{n}}-k_{n} \cdot g_{n}=0 \\
\left(o_{n}^{d} \ldots o_{n}\right)=x_{n} \\
\dot{g_{n}}=-g_{n}+\nabla_{x_{1}} P\left(x_{1} \ldots x_{3}\right) \\
\dot{h_{n}}=-h_{n}+\nabla_{x_{1}}^{2} P\left(x_{1} \ldots x_{3}\right)
\end{array} .\right.
$$

As mentioned earlier, a number of works considered the problem of the quality of transient processes in systems for searching for an extremum with auxiliary modulation.

Hessian and the gradient are in most cases in a nonlinear relationship, the elimination of this relationship is difficult, since in some cases, at the extremum point, it is impossible to obtain the inverse of the Hessian value (as is done in some continuous analogs of Newton's method), and establishing the exact relationship is a nontrivial problem.

Thus, the set of second derivatives along the corresponding extremum search channels can be represented as a vector field distorting the transient process. A number of ways have been proposed to establish the influence of the Hessian on the gradient.

One of these methods is the so-called. "Nesterov's accelerated gradient flows", which have the following general form:

$$
\ddot{\mathrm{x}}+\alpha \cdot \dot{\mathrm{x}}-\beta \nabla^{2} \mathrm{f}(\mathrm{x}) \cdot \dot{\mathrm{x}}-\nabla \mathrm{f}(\mathrm{x})=0,
$$

where $\mathrm{x}, \dot{\mathrm{x}}, \ddot{\mathrm{x}}$ - adjustable coordinate for finding the extremum and a number of its derivatives; $\nabla \mathrm{f}(\mathrm{x})$ and $\nabla^{2} f(x)-$ gradient and Hessian of the maximized extremal function $\mathrm{f}(\mathrm{x})$.

Using some technologies of adaptive and nonlinear control, it is possible to transform the gradient flow in the system.

The new gradient flow will correspond to the new behavior of the state-variables of the electrical complex, and taking into account this modification, the system of differential equations describing the behavior of an electrical complex as a dynamic system has the form: 


$$
\mathrm{F}=\left\{\begin{array}{c}
\ddot{\mathrm{x}}_{1}+\mathrm{A}_{1} \cdot \dot{\mathrm{x}}_{1}-\mathrm{B}_{1} \cdot \mathrm{h}_{1} \cdot \dot{\mathrm{x}}_{1}-\mathrm{k}_{1} \cdot \mathrm{g}_{1}=0 \\
\mathrm{~T}_{\mathrm{act}_{1}} \cdot \dot{\mathrm{o}}_{1}=-\mathrm{o}_{1}+\mathrm{x}_{1} \\
\mathrm{~g}_{1}=-\mathrm{g}_{1}+\nabla_{\mathrm{x}_{1}} \mathrm{P}\left(\mathrm{x}_{1} \ldots \mathrm{x}_{3}\right) \\
\dot{\mathrm{h}_{1}}=-\mathrm{h}_{1}+\nabla_{\mathrm{x}_{1}}^{2} \mathrm{P}\left(\mathrm{x}_{1} \ldots \mathrm{x}_{3}\right) \\
\ddot{\mathrm{x}}_{2}+\mathrm{A}_{2} \cdot \dot{\mathrm{x}}_{2}-\mathrm{B}_{2} \cdot \dot{\mathrm{h}}_{2} \cdot \dot{\mathrm{x}}_{2}-\mathrm{k}_{2} \cdot \mathrm{g}_{2}=0 \\
\mathrm{~T}_{\mathrm{act}_{2}} \cdot \dot{o_{2}}=-\mathrm{o}_{2}+\mathrm{x}_{2} \\
\dot{\mathrm{g}_{2}}=-\mathrm{g}_{2}+\nabla_{\mathrm{x}_{2}} \mathrm{P}\left(\mathrm{x}_{1} \ldots \mathrm{x}_{3}\right) \\
\dot{\mathrm{h}_{2}}=-\mathrm{h}_{2}+\nabla_{\mathrm{x}_{2}}^{2} \mathrm{P}\left(\mathrm{x}_{1} \ldots \mathrm{x}_{3}\right) \\
\ddot{\mathrm{x}}_{3}+\mathrm{A}_{3} \cdot \dot{\mathrm{x}}_{3}-\mathrm{B}_{3} \cdot \mathrm{h}_{3} \cdot \dot{\mathrm{x}}_{3}-\mathrm{k}_{3} \cdot \mathrm{g}_{3}=0 \\
\mathrm{~T}_{\mathrm{C}} \cdot \dot{\mathrm{o}_{3}}=-\mathrm{o}_{3}+\mathrm{x}_{3} \\
\dot{g_{3}}=-\mathrm{g}_{3}+\nabla_{\mathrm{x}_{3}} \mathrm{P}\left(\mathrm{x}_{1} \ldots \mathrm{x}_{3}\right) \\
\dot{\mathrm{h}_{3}}=-\mathrm{h}_{3}+\nabla_{\mathrm{x}_{3}}{ }^{2} \mathrm{P}\left(\mathrm{x}_{1} \ldots \mathrm{x}_{3}\right)
\end{array}\right.
$$

\section{Numerical Experiments and Results}

In this part of the article, we discuss the results of computational experiments, provide key explanatory and illustrative materials. The results of calculating the parameters and modeling are shown in the corresponding tables and graphs.

As noted above, there are assumptions, in which the calculation of volt-watt curves is greatly simplified. Namely, if the component $\mathrm{I}_{\mathrm{mp}} \cdot \mathrm{R}_{\mathrm{s}}$ is quite small. We obtained the exact values $R_{s}$ и $R_{\text {sh }}$, then $I_{0}$. Then we adjusted the value of the scale factor $n$.
Tables 1, 2 shows the calculation results for a sample of solar batteries quoted from [20].

With regard to transient processes, it is advisable to investigate the damping properties of the transformed gradient flow at a high gain coefficients. For simplicity, let's take $\mathrm{T}_{\text {act }_{1}}=\mathrm{T}_{\mathrm{act}_{2}}=0.01, \mathrm{~T}_{\mathrm{C}}=10^{-8}$, $\mathrm{A}_{1}=\mathrm{A}_{2}=\mathrm{A}_{3}=1$, and $\mathrm{B}_{1}=\mathrm{B}_{2}=\mathrm{B}_{3}=[0.2045 ; 2]$ with step 0.5 for Experiment No. 1 and $B_{1}=B_{2}=$ $=\mathrm{B}_{3}=[0.3 ; 2]$ with step 0.5 for Experiments No. 2 . In all cases $\mathrm{k}_{1}=\mathrm{k}_{2}=\mathrm{k}_{3}=3$. Start and end positions for coordinates electric drives are shown in Table 2 . Initial point for voltage $\mathrm{V}$ is randomly selected from the range $\left[0 ; \mathrm{V}_{\mathrm{oc}}\right]$, and the end value is in the vicinity $\mathrm{V}_{\mathrm{mp}}$.

Figs. 2 and 3 shows the V-I and V-Wt curves calculated by Equation (3)-(6). They help to assess the similarity between both the data from [20], and the typical modes of operation. It can be seen that the inconsistencies in the data from [20] and in our calculations are irrelevant.

Using an solar position online calculator (SPA) [25] and [27], we obtained the Sun angles for July 15, 2021. These angles are shown in Table 3.

Figs. 4 and 5 show the transients for the coordinate electric drives.

$\mathrm{I}-\mathrm{V}$ curve data (short circuit $\mathrm{V}=\mathbf{0}, \mathbf{I}=\mathbf{I}_{\mathrm{sc}}$, open circuit $\mathrm{V}=\mathrm{V}_{\mathrm{oc}}, \mathbf{I}=\mathbf{0}$, and the maximum power $V=V_{m p}, I=I_{m p}$ points) of several solar cells [20]

\begin{tabular}{|c|c|c|c|c|c|c|}
\hline $\begin{array}{c}\text { No. } \\
\text { of Experiment }\end{array}$ & Reference & $\mathrm{V}_{\mathrm{oc}}$ & $\mathrm{I}_{\mathrm{sc}}$ & $\mathrm{V}_{\mathrm{mp}}$ & $\mathrm{I}_{\mathrm{mp}}$ & $\mathrm{T}$ \\
\hline 1 & Kennerud, 1969 & 0.420 & 0.804 & 0.316 & 0.698 & 330 \\
\hline 2 & PSM-150 & 32.9 & 8.21 & 26.3 & 7.61 & 298 \\
\hline
\end{tabular}

1-Diode model values from different solar cells (data from [20])

Table 2

\begin{tabular}{|c|c|c|c|c|c|c|}
\hline $\begin{array}{c}\text { No. } \\
\text { of Experiment }\end{array}$ & Reference & $\mathrm{R}_{\mathrm{s}}$ & $\mathrm{R}_{\mathrm{sh}}$ & $\mathrm{I}_{0}$ & $\mathrm{P}_{\max }$ & $\mathrm{n}$ \\
\hline 1 & Kennerud, 1969 & $0.31606 \mathrm{e}-1$ & 9.9227 & $5.25 \mathrm{E}-06$ & 0.208 & 1.37 \\
\hline 2 & Cubas, 2014 & 0.83777 & 44.493 & $9.1 \mathrm{E}-07$ & 192.5 & 70.2 \\
\hline
\end{tabular}

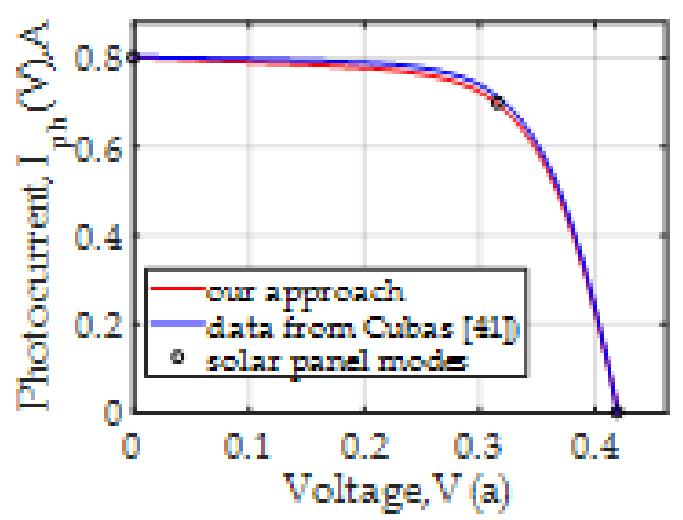

a)

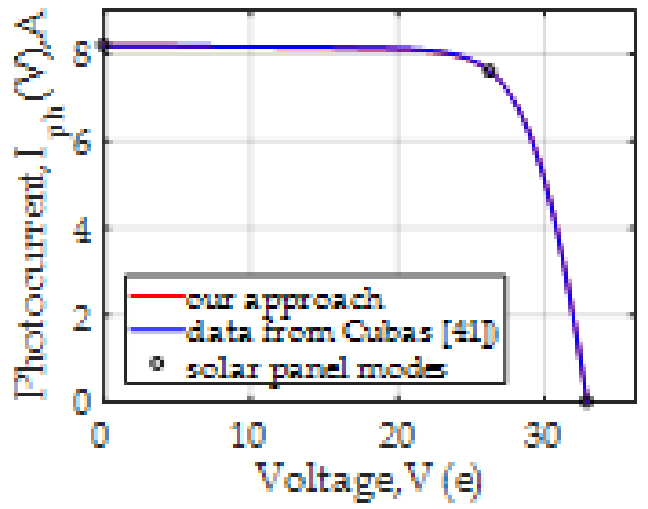

b)

Fig. 2. Volt-ampere curves in range $0 \leq V \leq V_{\text {oc }}$ : $a$ - Experiment 1; b - Experiment 2 


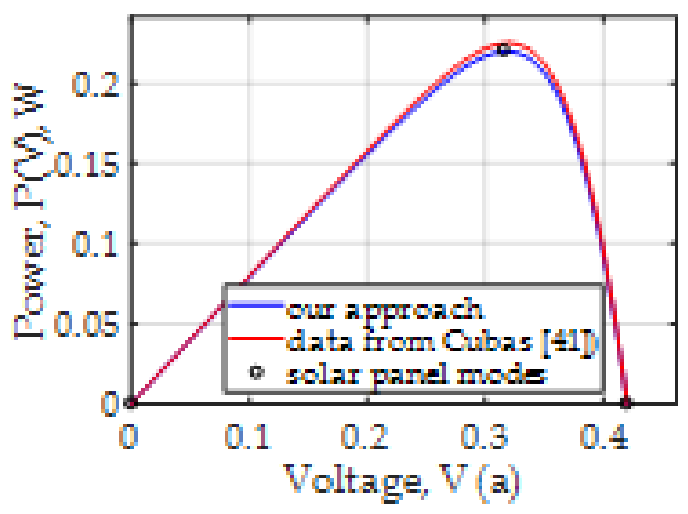

a)

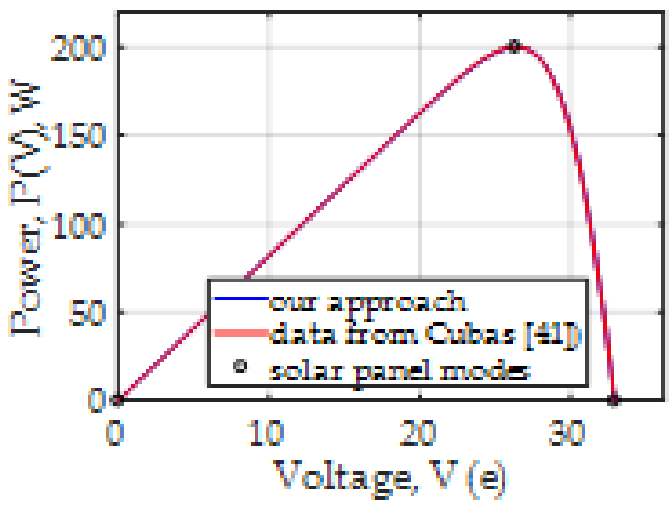

b)

Fig. 3. Volt-watt curves in range $0 \leq V \leq V_{o c}$ : $a$ - Experiment 1; $b$ - Experiment 2

Allocated time intervals for modeling extremum seeking control systems in Chelyabinsk on July 15, 2021 from 8:00 AM to 8:00 PM according to NREL MIDC SPA

\begin{tabular}{|c|c|c|c|c|}
\hline Experiment & Reference & Time & TEA (corrected), ${ }^{\circ}$ & AA (eastward from N), \\
\hline \multirow{2}{*}{1} & \multirow{2}{*}{ Kennerud, 1969 } & $8: 00: 00$ & 26.062834 & -90.849174 \\
\cline { 3 - 5 } & & $9: 00: 00$ & 34.561596 & -78.02713 \\
\hline \multirow{2}{*}{2} & \multirow{2}{*}{ Cubas, 2014 } & $9: 00: 00$ & 34.561596 & -78.02713 \\
\cline { 3 - 5 } & & $10: 00: 00$ & 42.627950 & -63.434196 \\
\hline
\end{tabular}

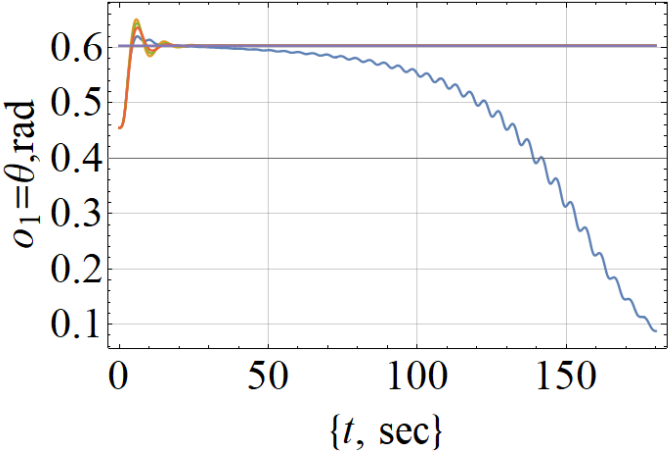

a)

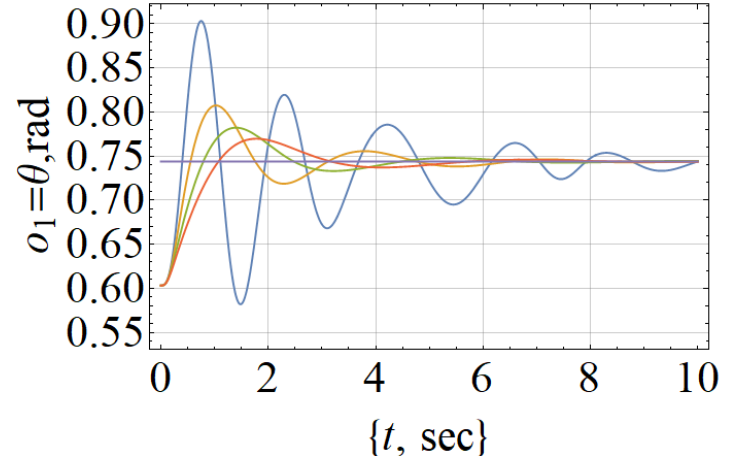

b)

Fig. 4. Comparison of electric drive zenith positions for experiments $(1,2)$ :

a - Experiment 1; b - Experiment 2. In the case of a more powerful solar battery in transients, nonlinear oscillations are observed at a fixed coefficient $A$ and with a change $B_{1}=B_{2}=B_{3}=[0.2045 ; 2]$ and $B_{1}=B_{2}=B_{3}=[0.3 ; 2]$, respectively. It can be noted that at a certain range of the coefficient $B$, these oscillations stop abruptly, and the coefficient $B$ has little effect on the form of transient processes

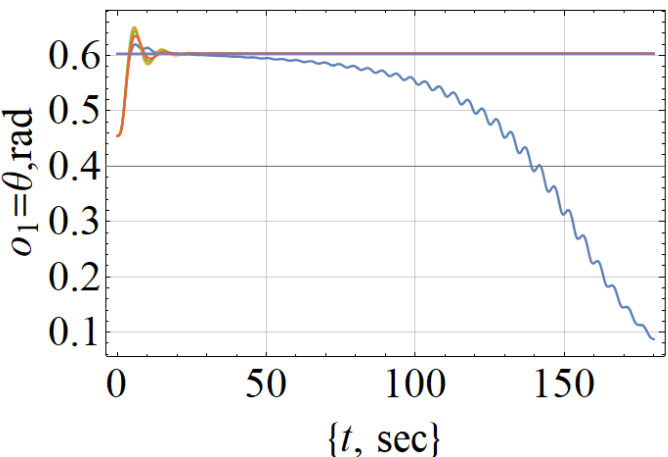

a)

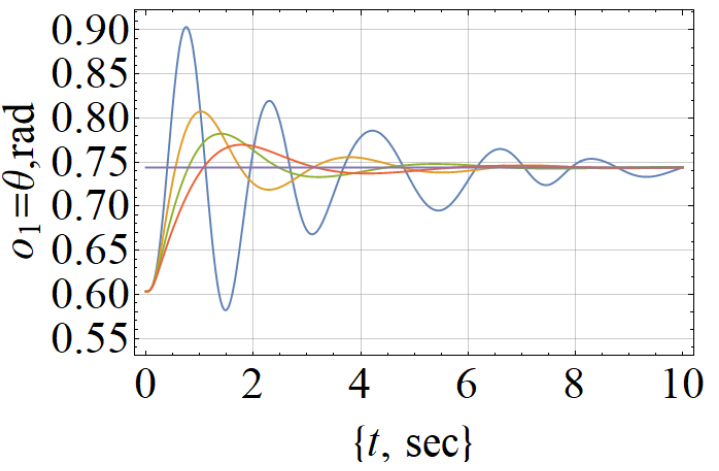

b)

Fig. 5. Comparison of electric drive azimuth positions for experiments $(1,2)$ :

a - Experiment 1; b - Experiment 2. A similar picture is observed in this case. Summarizing what we have seen, we can assume that by choosing the damping coefficient $\mathrm{B}$, we bring the system to the stability boundary, which is confirmed by weakly damped oscillations or the unstable behavior of the controlled coordinate 


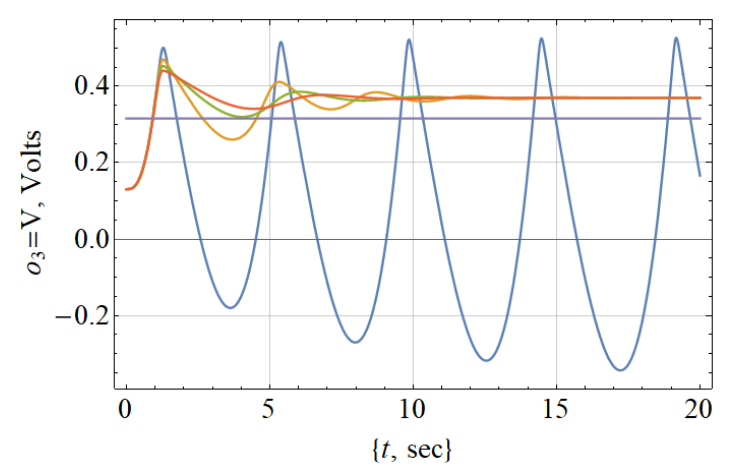

a)

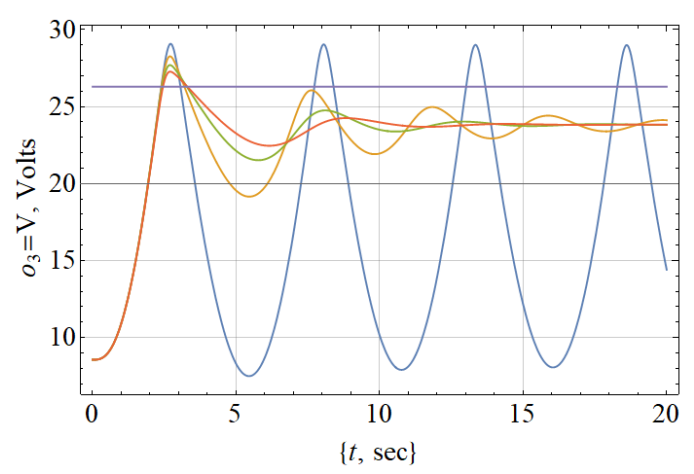

b)

Fig. 6. Comparison of voltage for various experiments (1, 2): a - Experiment 1; b - Experiment 2

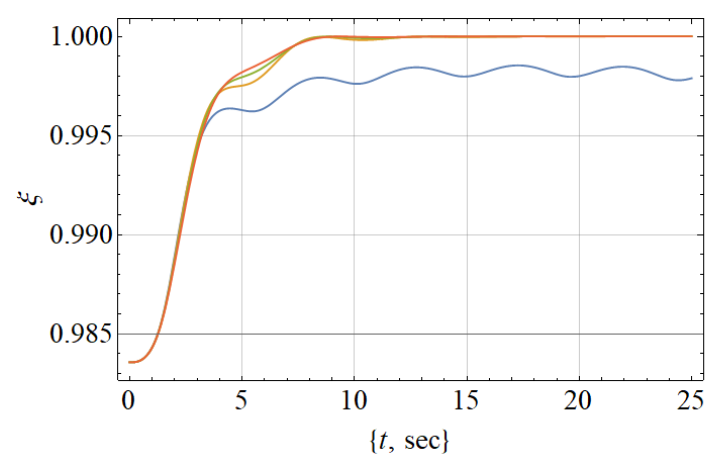

a)

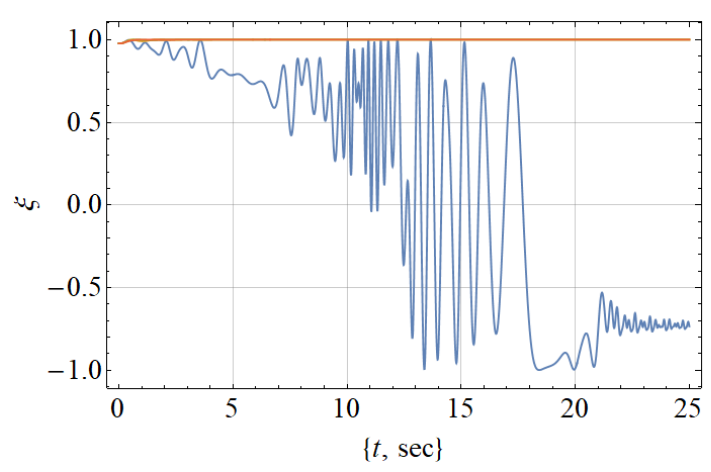

b)

Fig. 7. Comparison incidence coefficient $\xi$ for various experiments (1, 2): a - Experiment 1; b - Experiment 2

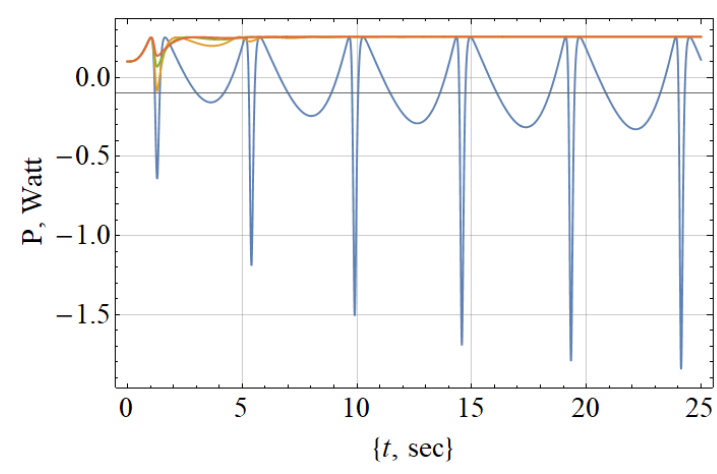

a)

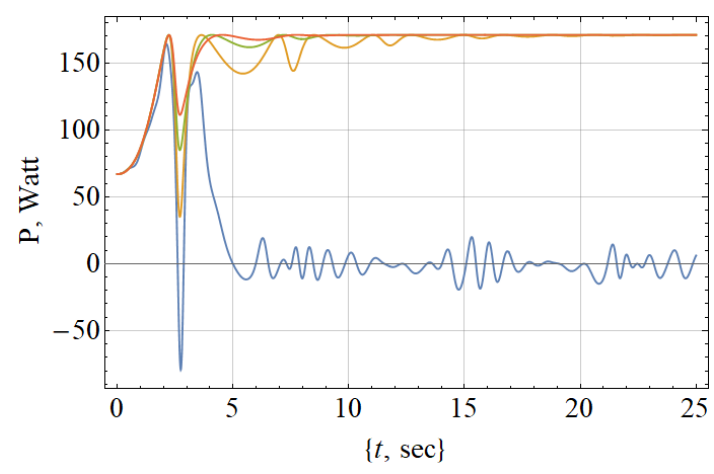

b)

Fig. 8. Comparison of solar battery power for various experiments (1, 2): a - Experiment 1; b - Experiment 2

The nonlinear behavior of a system with a Nesterov's gradient flow (9) at the stability boundary or with a weak damping is reflected in the transient of the solar battery voltage condition.

It should be noted that in the case of a gradient flow with good damping properties, the transients resemble those occurring in linear systems, despite the fact that the system of differential equations is nonlinear. The results are shown in Figs. 6-8.

\section{Discussion. Interpretation of the Results.}

Limitations of the Study in Question

In a general case, the study of multi-parameter systems can be complicated by the fact that many tu- ning parameters may not have an explicit physical meaning. This is a disadvantage of many proposals considered in other works on the topic. In our case, transient processes in the circuits depend on the parameters that have a very clear physical meaning. Among other things, it is sometimes difficult to determine, which of the parameters are the most important, how they relate to each other, and by which groups the results should be presented. In our case, there is one key parameter determining the rate of transient processes in the system along with a couple of auxiliary ones that determine the damping properties of the object, as well as, presumably, the properties of oscillation. All this, together with quasi-linear 
behavior, suggests that representing transient processes would make understanding dynamics even more intuitive. But the system is nonlinear, i.e., Laplace transforms are impossible for it. We've faced this problem and we are suggesting a possible way to solve it. The results will be published in other papers.

Two other, more general questions are:

1 . Which adaptation algorithm to choose to transform the gradient flow?

2. What is the process, in which electrical energy is converted to mechanical and how does it occur within the complex?

These issues will also be considered in other publications.

\section{Conclusions}

We presented some development results of novel extremum seeking controller based on Nesterov's gradient flows that achieves convergence to an arbitrarily small neighborhood of the set of optimizers of the cost function. Our results establish that for arbitrarily large compact sets of initial conditions, and arbitrarily small neighborhoods of the optimizer, the controller can be tuned to guarantee convergence taking into account the influence of the Hessian, as well as with tuning parameters that have a fairly clear physical meaning. Future directions will study the development of a linear analysis method using the apparatus of transfer functions and frequency characteristics, as well as refinement of the gradient flow transformation algorithm with the subsequent publication of these results.

In the broadest context, the results, clearly, cannot be called completely comprehensive. First of all, they highlite an important problem related to the development of new control systems for tracking systems for the Sun, namely, the creation and accurate analytical study of adaptive control systems. Our future work will be carried out in this field.

The reported study was funded by RFBR, project number 19-31-90156.

\section{References}

1. Kirpichnikova I.M., Sologubov A.Y. Multivariable Control of Solar Battery Power by Extremum Seeking : Starting from Linear Analysis. Machines, 2019, vol. 7, no. 4, pp. 64. DOI: 10.3390/machines7040064

2. Demenkova T.A., Korzhova O.A., Phinenko A.A. Modelling of algorithms for solar panels control systems. Procedia - Procedia Computer Science. The Author(s), 2017, vol. 103, no. October 2016, pp. 589-596. DOI: 10.1016/j.procs.2017.01.072

3. Pakkiraiah B., Sukumar G.D. Research Survey on Various MPPT Performance Issues to Improve the Solar PV System Efficiency, 2016, vol. 2016. DOI: 10.1155/2016/8012432

4. Ram J.P., Babu T.S., Rajasekar N. A comprehensive review on solar PV maximum power point tracking techniques. Renewable and Sustainable Energy Reviews. Elsevier, 2017, vol. 67, pp. 826-847. DOI: 10.1016/j.rser.2016.09.076

5. Sumathi V. et al. Solar tracking methods to maximize PV system output - A review of the methods adopted in recent decade. Renewable and Sustainable Energy Reviews. Elsevier, 2017, vol. 74, no. February 2016, pp. 130-138. DOI: 10.1016/j.rser.2017.02.013

6. Dogga R., Pathak M.K. Recent trends in solar PV inverter topologies. Solar Energy. Elsevier, 2019, vol. 183, no. February, pp. 57-73. DOI: 10.1016/j.solener.2019.02.065

7. Ahmad R., Murtaza A.F., Ahmed H. Power tracking techniques for efficient operation of photovoltaic array in solar applications - A review. Renewable and Sustainable Energy Reviews. Elsevier Ltd, 2019, vol. 101, no. November 2017, pp. 82-102. DOI: 10.1016/j.rser.2018.10.015

8. Tan C.F., Khalil S.N. Fuzzy rule-based model for optimum orientation of solar panels using satellite image processing Fuzzy rule-based model for optimum orientation of solar panels using satellite image processing. Journal of Physics: Conference Series, 2017.

9. Ya'u M.J. A Review on solar tracking systems and their classifications. Journal of Energy, Environmental \& Chemical Engineering, 2017, vol. 2, no. 3, pp. 46-50.

10. Hamid A.R. et al. A review on solar tracking system. Proceeding National Innovation and Invention Competition Through Exhibition (iCompEx'17), 2017.

11. Al-Rousan N., Isa N.A.M., Desa M.K.M. Advances in solar photovoltaic tracking systems: A review. Renewable and Sustainable Energy Reviews. Elsevier Ltd, 2018, vol. 82, no. January, pp. 2548-2569. DOI: 10.1016/j.rser.2017.09.077

12. Singh R. et al. An imperative role of sun trackers in photovoltaic technology: A review. Renewable and Sustainable Energy Reviews, 2018, vol. 82, pp. 3263-3278. DOI: 10.1016/j.rser.2017.10.018

13. Hafez A.Z., Yousef A.M., Harag N.M. Solar tracking systems: Technologies and trackers drive types A review. Renewable and Sustainable Energy Reviews. Elsevier Ltd, 2018, vol. 91, no. March, pp. 754-782. DOI: 10.1016/j.rser.2018.03.094

14. Esram T., Chapman P.L. Comparison of Photovoltaic Array Maximum Power Point Tracking Techniques, 2007, vol. 22, no. 2, pp. 439-449. DOI: 10.1109/tec.2006.874230 


\title{
Альтернативные источники энергии
}

15. Trollberg O., Jacobsen E.W. On the Convergence Rate of Extremum Seeking Control. 2014 European Control Conference, ECC 2014, 2014, pp. 2115-2120. DOI: 10.1109/ecc.2014.6862265

16. Ghaffari A., Krstić M., Nešić D. Multivariable Newton-based extremum seeking. Automatica. Elsevier Ltd, 2012, vol. 48, no. 8, pp. 1759-1767. DOI: 10.1016/j.automatica.2012.05.059

17. Poveda J.I., Krstic M. Fixed-Time Extremum Seeking, 2019, no. 1, pp. 2838-2843.

18. Bellia H. A detailed modeling of photovoltaic module using MATLAB. Nriag journal of astronomy and geophysics. National Research Institute of Astronomy and Geophysics, 2014. DOI: 10.1016/j.nrjag.2014.04.001

19. Bhatt P. et al. Optoelectronic modelling of perovskite solar cells under humid conditions and their correlation with power losses to quantify material degradation. Organic Electronics, 2016, vol. 39, pp. 258-266. DOI: $10.1016 /$ j.orgel.2016.10.015

20. Cubas J., Pindado S., Victoria M. On the analytical approach for modeling photovoltaic systems behavior. Journal of Power Sources, 2014, vol. 247, pp. 467-474. DOI: 10.1016/j.jpowsour.2013.09.008

21. Notton G. et al. Modelling of a double-glass photovoltaic module using finite differences. Applied Thermal Engineering, 2005, vol. 25, pp. 2854-2877. DOI: 10.1016/j.applthermaleng.2005.02.008

22. Wu H. A Maximum Power Point Detection Method for Photovoltaic Module Based on Lambert W Function Based on Lambert W Function. Mathematical Problems in Engineering, 2018, vol. 2018, p. 8. DOI: $10.1155 / 2018 / 8082960$

23. King D.L., Boyson W.E., Kratochvil J.A. Photovoltaic array performance model. Thesis for: PhD, 2004.

24. Khatib T., Elmenreich W. Modeling of Photovoltaic systems Using MATLAB. Hoboken, New Jersey, 2016. $242 \mathrm{p}$.

25. Reda I., Andreas A. Solar Position Algorithm for Solar Radiation Applications (Revised). NREL/TP-56034302. Golden (Colorado), 2008, no. January. 56 p. DOI: 10.2172/15003974

26. Johnson J. et al. Creating dynamic equivalent PV circuit models with impedance spectroscopy for arc fault modeling. 2011 37th IEEE Photovoltaic Specialists Conference, 2011, pp. 2328-2333. DOI: 10.1109/pvsc.2011.6186419

27. Sologubov A.Y., Kirpichnikova I.M. Calculation of the Parameters of the Daily Movement of the Sun. Contour Maps of Kinematic Parameters. 2019 International Conference on Industrial Engineering, Applications and Manufacturing (ICIEAM), 2019, pp. 1-6. DOI: 10.1109/icieam.2019.8742935

Received 20 August 2021

УдК 621.3.078.3

DOI: 10.14529/power210307

\section{МНОГОПАРАМЕТРИЧЕСКОЕ УПРАВЛЕНИЕ МОЩНОСТЬЮ СОЛНЕЧНОЙ БАТАРЕИ ПУТЕМ ПОИСКА ЭКСТРЕМУМА С ПОМОЩЬЮ ГРАДИЕНТНЫХ ПОТОКОВ, УПРАВЛЯЕМЫХ ГЕССИАНОМ}

\author{
А.Ю. Сологубов, И.М. Кирпичникова \\ Южно-Уральский государственный университет, г. Челябинск, Россия
}

\begin{abstract}
Мы представляем некоторые результаты разработки нового контроллера поиска экстремума на основе градиентных потоков Нестерова для систем слежения за Солнцем, который достигает сходимости к произвольно малой окрестности набора оптимизаторов функции стоимости. Наши результаты показывают, что для сколь угодно больших компактных наборов начальных условий и сколь угодно малых окрестностей оптимизатора контроллер может быть настроен так, чтобы гарантировать сходимость с учетом влияния гессиана, а также с параметрами настройки, которые имеют довольно четкую физический смысл. Гессиан, рассматриваемый как векторное поле, искажающее переходные процессы в системе, и его учёт является актуальной задачей, поскольку позволяет более гибко влиять на скорость переходных процессов, и за счет наделения системы некоторым демпфированием и сглаживанием, также улучшить их качество.

Ключевые слова: мощность солнечных батарей; отслеживание точки максимальной мощности; нелинейная система управления; система поиска экстремума; градиентный поток; гессиан.
\end{abstract}

Исследование выполнено при финансовой поддержке РФФИ в рамках научного проекта № 19-31-90156. 
Сологубов Андрей Юрьевич, аспирант кафедры «Электрические станции, сети и системы электроснабжения», Южно-Уральский государственный университет, г. Челябинск; andrewsteelmaker@gmail.com.

Кирпичникова Ирина Михайловна, д-р техн. наук, профессор, заведующий кафедрой «Электрические станции, сети и системы электроснабжения», Южно-Уральский государственный университет, г. Челябинск; kirpichnikovaim@susu.ru.

Поступила в редакцию 20 августа 20212.

\section{ОБРАЗЕЦ ЦИТИРОВАНИЯ}

Sologubov, A.Yu. Multivariable Control of Solar Battery Power: Electrotechnical Complex as Object with Hessian-Driven Gradient Flows / A.Yu. Sologubov, I.M. Kirpichnikova // Вестник ЮУрГУ. Серия «Энергетика». - 2021. - Т. 21, № 3. - С. 57-65. DOI: $10.14529 /$ power2 10307

\section{FOR CITATION}

Sologubov A.Yu., Kirpichnikova I.M. Multivariable Control of Solar Battery Power: Electrotechnical Complex as Object with Hessian-Driven Gradient Flows. Bulletin of the South Ural State University. Ser. Power Engineering, 2021, vol. 21, no. 3, pp. 57-65. DOI: $10.14529 /$ power 210307 